\title{
تقدير التعويض
}

عن الخطـأ

الباحث/ محد رفتت عبد الرؤوف 



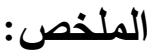

الخطأ وهو ركن من أركان المسئولية المدنية بنوعيها العقديه، التقصيرية وفي

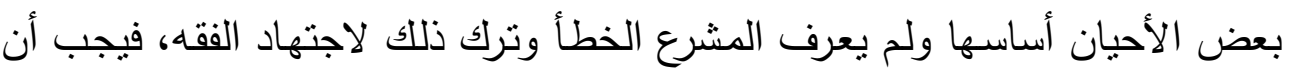
تجدر الإثشارة إلي ماهيه ومقدار وصور الخطأ الذي يستوجب التعويض، فالخطأ دل وإن يدل على الانحراف عن السلوك والإخلال بواجبات ومقتضيات الحيطة والحذر الحرد

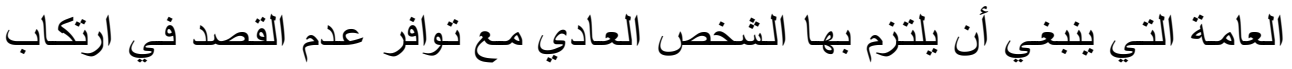

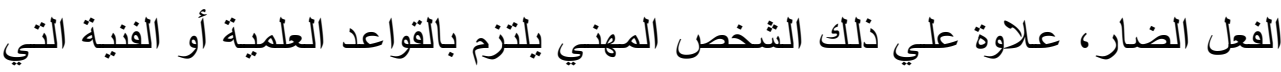

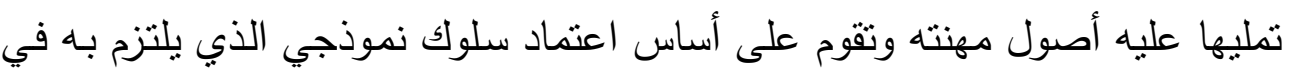

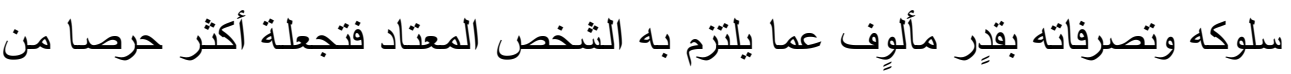
الثخص العادي لدرايته وخبرته وضعف احتمال صدور الخطأ المهني منه. أما عن درجة الخطأ،فيختلف ما بين خطأ بسيط وخطأ جسيم و خطأ بالغ

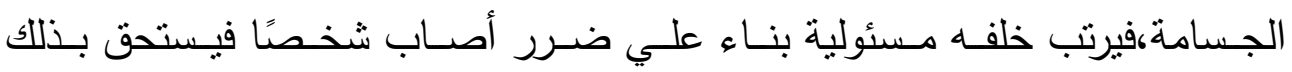

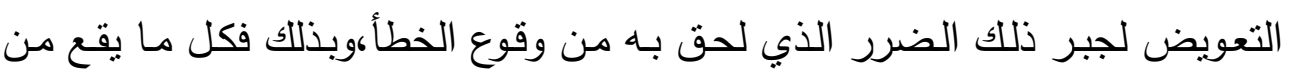
الثخص الذي ينتمي إلي مهنه يخرج عن المألوف الذي تحتمة علية أصول مهنته،

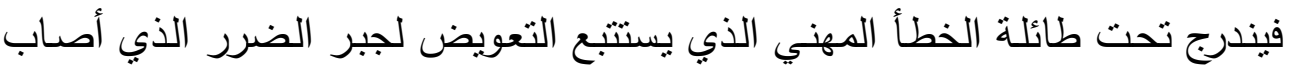

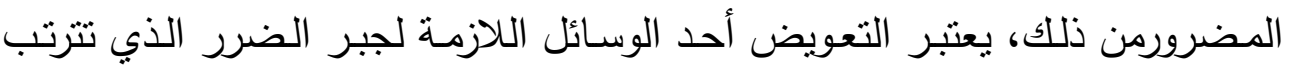

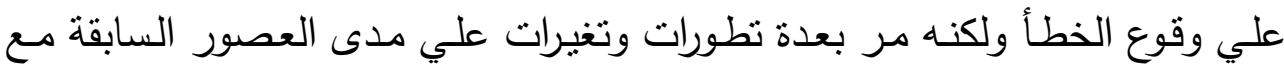
اختلاف النظم القانونية وظهر ذلك في العصور البدائية وإختلافها عن مبدأ وشكل التعويض ودورة في جبر الضرر ومدى موقف الثريعة الغراء من التعويض وخلطة بالجزاءات المالية وكذلك الضمان ومعايير تقدير التعويض، وكذلك اختلاف النظم

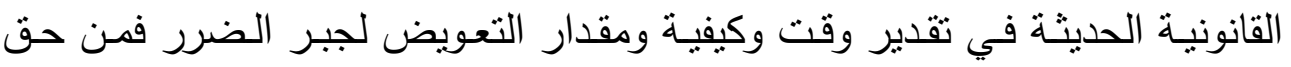

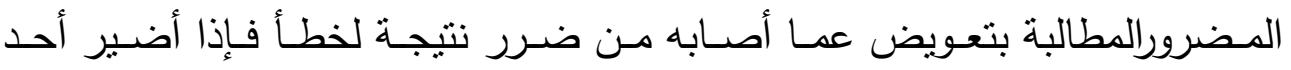
الأثخاص ؛بسبب خطأ مهني كلا علي قدر جسامته، متى توافرت الثروط اللازمة 
لقيام المسؤلية من خطأ وضرر وعلاقة سبيية وللمضروراللجوء إلى السبل التي حددها القانون برفع دعوى أمام القضاء للمطالبة بالتعويض عما أصابه من ضرر وللقاضي

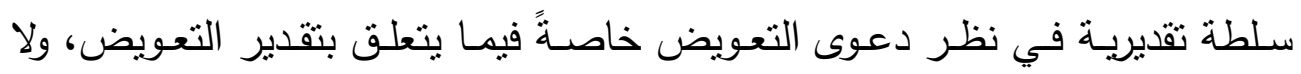
يخضع لرقابة محكمة النقض إلا فيما يتعلق بتوافرعناصر تقدير التعويض من عدمه

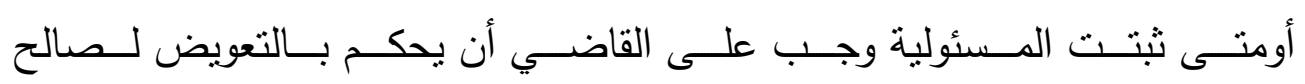
المضرورويشنرط في التعويض أن يجبر الضرر بالكامل،فيشمل الضرر المتوقع وغير المتوقع والضرر المستقبل وتفويت الفرصة.وللقاضي أن بستعين بكافة الوسائل المقررة له وإذا اشترك عدد من المتسببين في الخطأ قامت مسؤليتهم عن هذا الخطأ، وأصبح كل واحد منهم مسئولًا مسؤلية تضامنية مالم يتبين أن خطأ أحدهم ليس لله صلة البتة بالضرر الذي لحق بالمضرور ، ففي هذه الحالة تتتفي مسؤليته، وجدير بالذكر إن

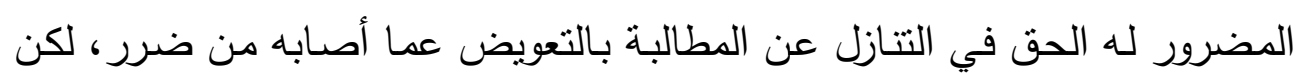
لابـد أن يكون هذا التـازل بعد وقوع الضرر، أمـا قبـل حدوثه، فلايجوز ذلك لأن المسؤلية في القانون المصري بحسب الأصل مسؤلية تقصيرية متعلقة بالنظام العام. وسوف يتم الوقوف على كافه النقاط سالفه الذكر في مجمل البحث المتقدم. 


\section{Summary:}

- The error is one of the pillars of civil liability in both nodal, tortious and sometimes basis and did not know the wrong legislator and left to jurisprudence, it should be worth noting the amount and the amount and the error that requires compensation, error is indicative of the deviation from behavior and breach of duties and requirements of public caution and caution In addition to that the professional person adheres to the scientific or technical rules dictated by the principles of his profession and is based on the adoption of a typical behavior in which he commits himself in his behavior and behavior in a familiar manner The usual person is committed to it, making it more careful for the average person to know him, his experience and the weakness of the possibility of issuing a professional error.

- The degree of error varies between a simple error and a serious error and a mistake of great gravity and placed behind him the responsibility to build on the damage suffered by a person injured and deserved compensation to redress that damage caused by the error and so everything that falls from the person who belongs to his profession out of the ordinary Which imposes on him the assets of his profession falls under the penalty of professional error, which entails compensation to redress the injury suffered by the injured Compensation is one of the necessary means to redress the damage caused by the error, but it has undergone several developments and changes over the past centuries with different legal systems and appeared in primitive times and different from the principle and form of compensation and a cycle of reparation and the extent of the position of the Sharia glue compensation and a mix of financial sanctions, Guarantee and compensation criteria, as well as the difference in modern legal systems in estimating the time, how and the amount of compensation for reparation, the injured person has the right to claim compensation for harm caused by a mistake. If a person is harmed by a professional error, For the responsibility of the error and damage and causal relationship. 
- In order to do so, the injured person shall resort to the means prescribed by law to bring a claim before the courts to claim compensation for the harm he suffered.

- The judge has discretionary power in the consideration of the compensation action, especially with regard to the assessment of compensation, and is not subject to the control of the Court of Cassation except in respect of the availability of the elements of the assessment of compensation or not. If the responsibility is established, the judge must award compensation in favor of the victim.

- Compensation is required to fully force the damage, including expected damage, unexpected damage and future loss of opportunity.

- In order to do so, the judge may avail himself of all the means prescribed to him. If a number of the wrongdoers participate, their responsibility for this error shall be liable to each of them, unless it becomes apparent that the fault of one of them is totally unrelated to the harm suffered by the injured person. His responsibility is gone.

- It is worth mentioning that the injured person has the right to waive the claim for damages. However, this waiver must be after the damage, but before it occurs, it is not permissible because the responsibility in the Egyptian law according to the origin is a tort liability related to public order.

- All the above mentioned points will be discussed in the overall advanced research. 


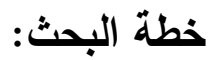

- مقدمة.

- المبحث الأول : الأساس القانوني للحق في التعويض - - المطلب الأول : المسئولية المدنية

- المطلب الثاني : الخطأ في المسئولية التقصيرية - - الفرع الأول : مفهوم الخطأ - - الفرع الثاني : درجات الخطأ - - الغصن الأول : الخطأ الجسيم

- - الغصن الثاني : الخطأ اليسير ( العادي ) - الفرع الثالث : أركان الخطأ - - الغصن الاول : الركن المادي - - البند الأول : المعيار الموضوعي - - البند الثاني : المعيار شخصي - - الغصن الثاني : الركن المعنوي ( الادراك ) - - البند الأول : موقف المشرع المصري - الفرع الرابع : إثبات الخطأ. - الغصن الأول : إثبات الخطأ عند المشرع المصري. - الغصن الثاني : إثبات الخطأ عند المشرع الفرنسي. - - المبحث الثاني : تقدير التعويض 
- المطلب الأول : سلطة قاضي الموضوع في تقدير التعويض

$$
\text { - - المطلب الثاني : التقدير الملزم للقاضي }
$$

- الفرع الأول : التقدير القانوني للتعويض.

- - الفرع الثاني : التقدير الاتفاقي للتعويض

- الخاتمه

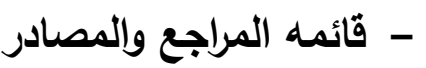

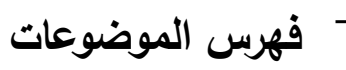


المسئولية التقصيرية إحدي صسور المسئولية المدنيـة وتبنى على الإخـلال بالالنزام القانوني العام الذي يقضي بعدم الإضـرار بالغير، وكل إخلال بهذا الالتزام العام يرتب المسئولية المدنية على المُخل ويسأل من جراء الإخلال تعويض علي ما ترتب علي فعله من أضرار للمضرور من جراء هذا الإخـلال بالالنزام العام والتطور الذي حدث في نظرية المسئولية التقصيرية وهو تأسيسها على فكرة الضرر، فلا يكفي أن يحدث الضرر بفعل شخص حتى بلزم ذلك الثخص بتعوبضه، بل يجب أن يكون

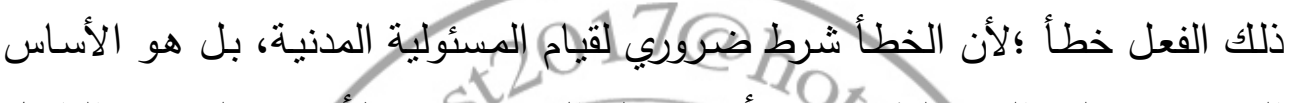

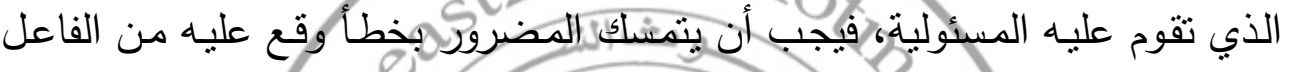
وعليه إثبات ذلك الإنستحقاق التعوض لجبر الضرم اللذّي أصسابه، وتعد المسئولية التقصيرية الثريعة العامُة للفيائولية المدنية. وقد أغفلت معزظم|التشريعات تعريف الخطأ تاركة ؛ياه إلى الفقهاء، وقد حاول هؤلاء منذ تقنين نابليون تُعريف الخطأ، فكانت تعريفاتهم كثيًرا ومتباينة وفقًا لنزعاتهم الثخصية، وكذلك حسب طروف المجيمع الأي يعيشون فيه من الناحية الاجتماعية والاقتصادية والثقافية ومنلبات هذا التطوروعلي ذللك يجن التعرض إلي مفهوم الخطأ

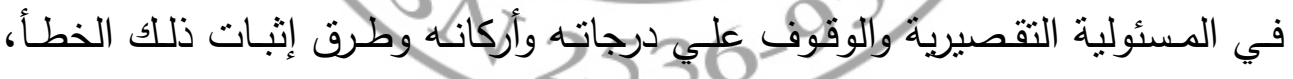
وأسـاس هذه المسئولية هو الخطأ الواجب الإثبات بمعنى أنه لا يفترض الخطأ من جانب المسئول،بل يكون على المضرور إثبات هذا الخطأ، وهذا ما يعرف بالمسئولية عن الفعل الثخصي، إلا إن المشرع ورغبـة منـه في تخفيف عبء الإثبـات على المضرور أنشأ لمصلحته قرائن قانونيـة تعفيه في بعض الأحيان من وجوب إثبات الخطأ على أساس أن المسئولية تعتبر في هذه الأحوال مفترضـة،أي إنها ترتكز على خطأ مفترض، ولقد أخذ الفقهاء الأوائل بالمذهب الذي يضيق من دائرة الخطأ ويحد بالتالي من قيام المسئولية المدنية والالتزام بالتعويض، وذلك يؤدي إلي ضياع حق 
المضرور في الحصول علي تعويض جراء ذلك الخطأ، و قد سلك المحدثون طريق التوسع في تعريف الخطأ لتسهيل قيام المسئولية، ولتيسير حصول المضرورين على تعويض عما أصابهم من ضرر.

وللقاضـي سلطة نقديريـة في نظر دعوى التعويض خاصـةً فيمـا يتعلق بتقدير

التعويض، ولا يخضع لرقابة محكمة النقض إلا فيما يتعلق بتوافر عناصر تقدير التعويض

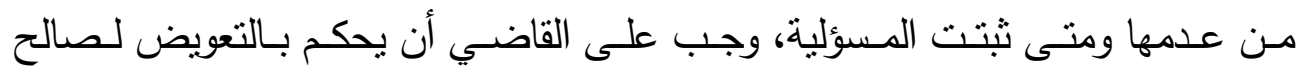
المضرور، ويشترط في التعويض أن يجبر الضرر بالكامل،فيشمل الضرر المتوقع وغير المتوقع والضرر المستقبل وغير تقويت الفرصـة، وللقاضـي في سبيل ذلك أن بستعين بكافة الوسائل المقررة لله،وإذا اشترك عدد من المتسبيين في الخطأ،قامت مسؤليتهم عن هذا الخطأ، وأصبح كل واحد منهم مسئول مسئولية تضامنية أو مجتمعة ما لم يتبين أن خطأ أحدهم ليس لله صلة البتة بالضرر الذي لحق بالمضرور ، ففي هذه الحالة تنتفي

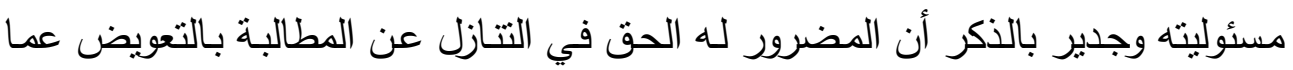

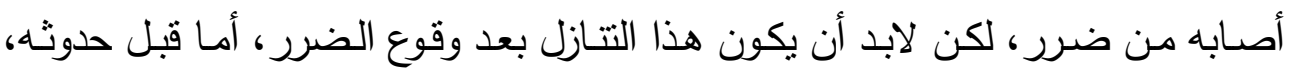

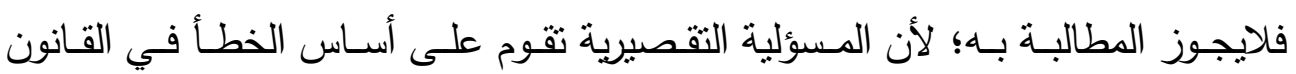
المصرى بحسب الأصل ومتعلقة بالنظام العام.

\section{الأهمبة العملية}

فتتمنل في كون الخطأ المهني يعتبرمن أهم النزاعات المطروحة ومثيرة للجدل

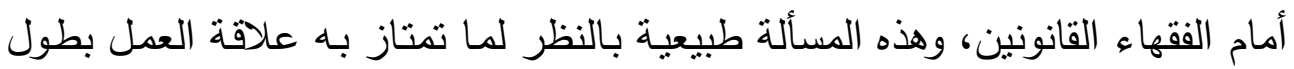
المدة نسبَّيا، والعامل من خلالها لبس معصومًا من الخطأ إضـافة إلى تتوع الالتزامات المهنية المفروضـة على عاتق العامل واختلاف مصادرها من جهة أخرى إلي جانب عن ما قد يقع من خطأ مهنى يسبب ضرر للشخص يستحق بموجبه التعويض بناء

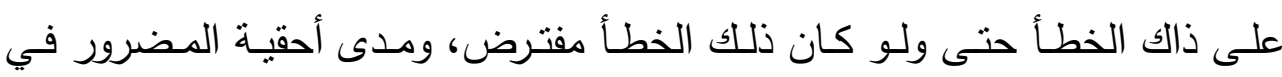
الحصول علي تعويض. 


\section{الغرض من دراسة}

هذا البحث تم اتبـاع مقارنـة بعض المفـاهيم النظريـة ببعضها البعض مـع استعمال نفس المنهج عند دراسة بعض الحالات علي ماهي عليه في القانون والقضاء المصري بما يقابلها في كل من فرنسا وعدة دول أخرى، وكذلك إثراء المكتبة القانونية للوقوف على مدى أحقية المضرور في الحصول على خطأ مهني من جراء الفعل الضار الذي لحق به ضرراً واجب الجبر •

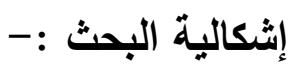

تتمنل إثكالية الدراسة في مدى أحقيه المضرور فى الحصول على تعويض جابر للضرر ترتب على قيام المسئولية المدنية. منهجية البحث :يتتاول الباحث موضوع البحث بإتباع المنهج المختلط للوقوف على أهميـة التعويض عن الخطأ الذي يعد صورة وركن من أركان المسئولية التقصيرية. 


\section{المبحث الأول}

\section{الأساس القانوني للحق في التعويض}

المسئولية المدنية هي التزام المدين بتعويض الضرر الذي ترتب على إخلاله

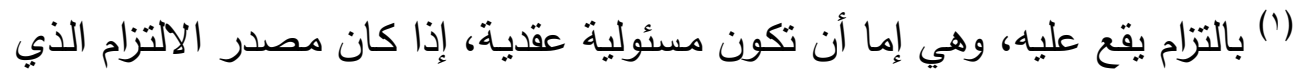

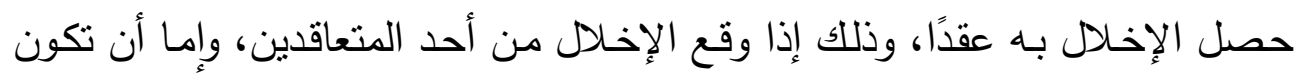
مسئولية تقصيرية إذا كان هذا الالتزام مصدره العمل غير المشروع صدر من الثخص الثص الذي قام بالعمل غير المشروع كتقصير أو امتتاع أو مخٍاف في تصرفه لآداب المهنه أو وقع من أحد تابعية أومن أحد الأشياء المكلف بحراستها، ومن بين ذلك التمبيز بين المسئولية القانونية والمسئولية الأدبية، والتي تتشأ عند إخلاء الشخص بقاعدة خلقية، وهي تستوجب جزاء أدبيًا بعيًّا عن دائرة القانون.

\section{المطلب الأول}

\section{المسئولية المدنية}

أما عن المسئولية المدنية تقوم على الإخلال بالتزام، وتستوجب لقيامها طرفين :أحدهما هوالمتضرر ،والآخر هوالذي نشأ من فعله الضرر الذي أحدثه أو سببه، وهذا لإنها على نحو ما نصت عليه المادة ( ب7 ( ) من القانون المدني المصري بقولها " كل هل خطأ سبب ضررًا للغير يلزم من ارتكبه بالتعويض"، وبالتالي، فإن المتسبب يسأل عن

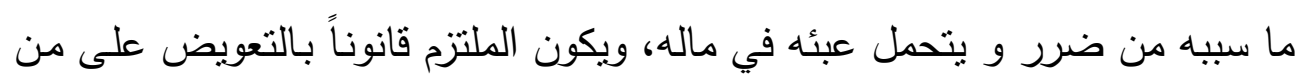

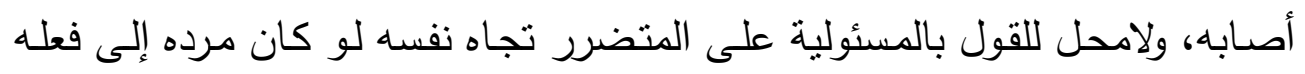

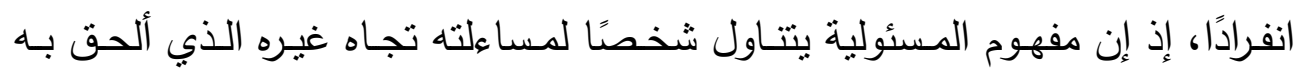

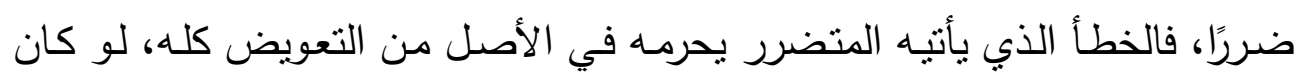

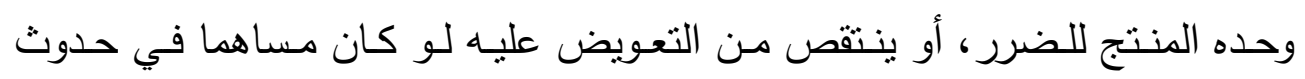


الحادث إلى جانب الذي يسأل عنه الثخص المتسبب في وقوع الضرر، والمسئولية المدنيـة نفسها ليست موحدة إذ تتقسم إلى مسئولية تقصيرية تترتب عن فعل غير

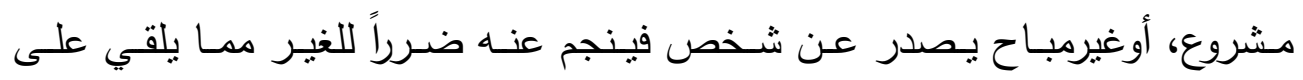
المسئول عنه التزام بتعويض الضرر سواء في صورة إصلاح الضرر أو دفع مبلغ من النقود، ومسئولية عقدية تتشأ عن عدم تتفيذ العقد، وهي بذلك تقرر مبدأ المسئولية والالتزام بالتعويض جزاء عدم تتفيذ الالتزامات الناشئة عن العقد المبرم بين طرفي التعاقد، وبالتالي فإن المسئولية العقديـة بهذا الشكل تؤدي إلى حرص المتعاقد على الثى تتفيذ التزامـه ليتجنب جزاء الإخـلال بمـا التزم بـه، و هذا مـا يرتب ضـمان أو حمايـة حقوق المتعاقد الآخر ، وعليه فإن كل هذا يحقق استقرارالمراكز القانونية و المعاملات بين الأفراد في المجتمع.

\section{المطلب الثاني}

\section{الخطأ في المسئولية التقصيرية}

أغفلت معظم النشريعات تعريف الخطأ وقد تركت تعريف الخطأ مهمة ملقاة على عاتق الفقهاء الذين يحاولون تعريف الخطأ فنتنج عن محاولتهم تعريفات متباينة تختلف وفق لنزاعاتهم الثخصية والاقتصاديه وحسب ظروف مجتمعهم الذي يعيشون فيه هذا ولم يسلم أي من هذه التعريفات من النقد إلا أن أصبح الاختيار بينها من وهن ولن

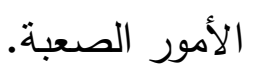

\section{الفرع الأول : مفهوم الخطأ :-}

يعرف أحد الفقهاء الخطأ بأنـه (؟) :" الإخـلال بواجب قانوني سواء أكان هذا

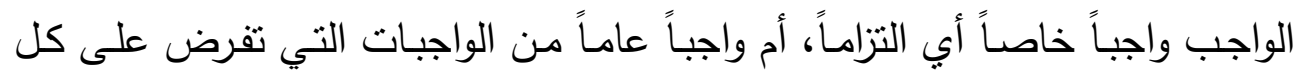
شخص يعيش في جماعة يحكمها القانون بأن يحترم حقوق الغير وحرياتهم وألا يرتكب مساساً بهذه الحقوق والحريات 
وينظر في هذا التعريف للخطأ علي أنه واجب قانوني يلتزم به الشخص الذي وقع منه الخطأ سواء كان هذا الواجب عامـا تجاه المجتمع اوخاصا تجاه افراد او فئه او جماعه محدده بعينها واشترط أن يكون هناك قانون ينظم العلاقات بين افراد ذلك هي المجتمع حيث أعتبر وقوع الخطأ من الشخص الذي قام بـه مساسا للحقوق والحريات الذي ينظمها القانون الذي يحكم المجتمع والتي تحتم علي من يعيش فيه إحترام تلك القواعد الحاكمه والمنظمه له وعدم المساس بها لذك يتضح تعريف الخطأ عند الدكتور جمبل الشرقاوي في تعريفه أن الخطأ واجب قانوني من شأنه عدم المساس بحقوق

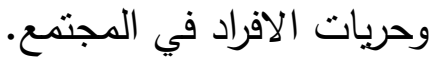
ويـرى جانـب مـن الفقهـ (r)" : أن الخطـأ عبـارة عـن "أنحـراف الشخص عـن السلوك المعتاد مع إدراكه لهذا الانحراف". ويعرفه رأي آخر (؛) : الخطأ بأنه " إخلال بواجب قانوني مقترن بإدراك المُخل

ويري رأي آخر (0) : عرف الخطأ بأنه " انحراف عن سلوك الشخص المعتاد الموجود في نفس الظروف الخارجية لمرتكب الضرر مع إدراك ذلك" وكذلك رأي أخير (`)عرف الخطأ بأنه " انحراف سلوك الثخص مع إدراكه لهذا الانحراف "

فكما يتضح من التعريفات السابقة أنهم جميعاً اتفقوا على أن الخطأ إنحراف عن السلوك المعتاد، وأثناروا لضروره توافر الادراك،فمناط الخطأ لديهم توافر أركانها المادي والمعنوي، ويؤخد بعين الإعتبار وجود بعض التشريعات أكتفت بالركن المادي فقط دون الالتفات للركن المعنوي ومن ذلك التشريع الكويتي والبحريني. فالركن المادي وهو " التعدي " والانحراف في السلوك المعتاد أمسا عن الركن المعنوي وهو " الإدراك " فلا يكتفي بتوافر التعدي توافر ركن الخطأ في المسئولية، 
وإنما لابدّ من أن يقع التعدي من شخص مدرك لنتائج أفعاله.

ومن ثمّ يجب أن يكون المعتدي مميزاً فمن انعدم الإدرالك والتمييز لديه لا يعد مسئولا.

وكما أشـارت كافه التعريفات السابقه للخطأ من الفقهاء الأجـاء دون الوقوف

علي تعريف محدد قاطع للخطأ إلا إنهم توصلوا إلي تعريف الخطاء بالانحراف عن سلوك معين دون وضـع ضوابط لهذا السلوك ومقداره، وكذلك الوقوف علي الظروف الخارجيـة مـع اختلافهـ من الشخص العـادي عنـه من الشخص المتبصرالذي قد يتبع لوائح وقانين مهنه معينه تزيد من مقدار التبصر لديه الذي بمقتضاه تتشأ المسئوليه التي تستوجب التعويض.

هذا و يرى أحد الفقهاء (v) أن الخطأ لا يتضمن ضـابط يبين هذا الطريق الوسط الذي يعصم الثخص من الخطأ إذ هو سلكه واتبعه.

إن النتيجة التي يمكن استخراجها من خلال ما تم التعرض إليه عند تطرقنا لمفهوم الخطأ ومن خلال مختلف الآراء الفقهية التي قيلت فيه، أنه يجب الإبقاء على الخطأ كشرط وكأساس للمسئولية المدنية ؛أي لامسئولية مدنية بدون خطأ، هذا هو المبدأ العام.

الفرع الثاني : درجات الخطأ :-

الخطأ من الناحية العملية ينقسم إلي درجات متعددة ولم يتفق الفقهاء على تمييز كل منها،إنما لا يزال الأمر محل جدال،فيختلف ما بين خطأ بسيط وخطأ جسيم وخطأ بالغ الجسامة فيرتب خلفه مسئولية بناء علي ضرر أصساب شخصًا وقع عليه الضرر، فيستحق بذلك التعويض لجبر ذلك الضرر الذي لحق بـه من وقوع الخطأ، وبذلك فكل ما يقع من الثخص الذي ينتمي إلى مهنه يخرج عن المألوف الذي تحتمة

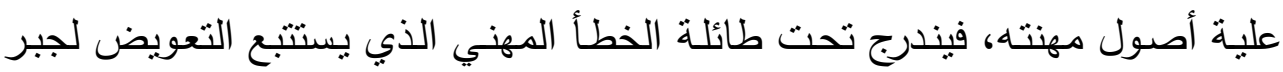
الضرر الذي أصاب المضرور • 
الغصن الأول : الخطأ الجسيم :-

وهو الخطأ الذي لا يرتكبه أقل الناس إهمالا وأكثرهم جهلا،وقد ألحق هذا

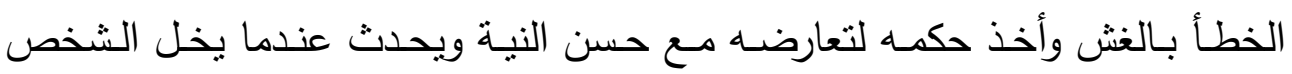
بواجبات قانونية على جانب من الأهمية، ومن صوره " الخطأ الذي لا يغتفر ، إذ إنه في الواقع أثد من الخطأ الجسيم ويكون عادة على قدر كبير من الجسامة و الخطورة.

$$
\text { الغصن الثاني : الخطأ اليسير ( العادي ) :-- }
$$

ويعرف عادة بأنسه الخطأ الذي لا يقع من شخص منوسط الحرص والعناية

وبطلق عليه أيضًا اسم الخطأ العادي ويوصف بلفظ ( الخطأ ) مجردًا من كل وصفٍ فهو يكون أقل خطورة من الخطأ الجسيم، و إذا كانت القاعدة العامة في هذا النوع من الأخطاء أنها تستحق التعويض كغيرها، فإن هناك استثناءات لا تجعل لهذا الخطأ اليسير أي اعتبار أثناء تقدير التعويض كما هو الحال بالنسبة للمسئولية التقصيرية للقضاة.

غير أن الصعوبة تكمن في معرفة المعيار الذي يتعين على القاضي اعتماده لضبط سلوك الأفراد، ذلك أن الأفراد ليسوا على مستوى واحد من الحيطة و التبصر و اليقظة والخبـرة (^)، الأمـر الذي يفرض على المحكمـة الخيـار بين نطبيق المعيـار الثخصسي الذي يميز سلوكيات الأفراد و معاملتهم على قدر إمكانياتهم الذاتيـة من فطنة أو غباوة، أو تطبيق المعيار الموضوعي الذي يتعامل مع كافة الأفراد باعتبار إمكانيات الفرد العادي متوسط الخبرة والذكاء، ولكن الفقه والقضاء قد أستتد علي تطبيق المعيار الموضوعي. الفرع الثالث : أركان الخطأ :يشترط لتوافر الخطأ الذي تترتب عليه قيام المسئولية التقصيرية توافرالركن المادي المتمثل في القيام بالفعل المرتب للضرر إيجاباً أو الامتتاع عن القيام بواجب لتبن 
قانوني سلباً يقرره القانون علي عاتق من قام بالفعل الضار بالإمتتاع والركن الآخر المعنوي،وهو مدي إدرالك وتمييز من قام بالفعل المرتب للضرر وبالتالي قيام المسئولية

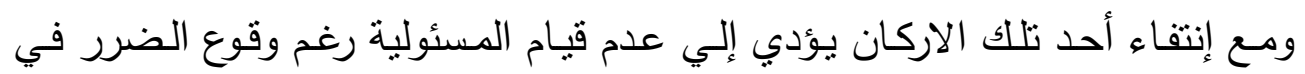
بعض الأحيان وسوف ينم الوقوف علي تلاك الأركان علي النحو النالي.

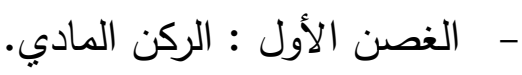

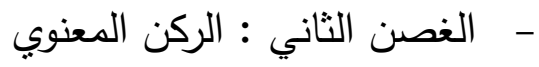

الغصن الاول : الركن المادي: - المي

الذي يتمثل في الفعل الضار أو القيام باي تصرف في صورته الإيجابيه أوفي صورته السلبية بالامتتاع عن القيام بالفعل الذي يتحتم عليه القيام به بموجب القانون او الإلتزام. فالركن المادي للخطأ هو " التعدي والانحراف عن سلوك الرجل المعتاد الموجود في نفس الظروف العاديه التي يكون فيها من يراد الحكم على سلوكه" ويقدر

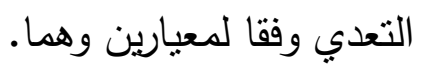
البند الأول : المعيار الموضوعي. وفي المعيار الموضوعي ينظر إلى الفعل ذاته فيما إذا كان يشكل انحرافًا عن سلوك معين وهو سلوك الرجل المعتاد الموجود في نفس الظروف العاديه دون الالتفات لظروف الفاعل الثخصية، وبالنسبة للمعيار الذي يحدد انحراف سلوك الثخص عن السلوك المعتاد يميز الفقه الفرنسي في هذا الصدد بين الفعل المتعدد والفعل غيرالمتعدد، ويجعل المعيار في الفعل المتعدد الذي قصد صاحبه به الإضرار بالغير معيارا شخصيا لقياس نية الفاعل.

فإذا كان الفعل واقعا نتيجة إهمال إي كان فعلا غير عمدي يكون

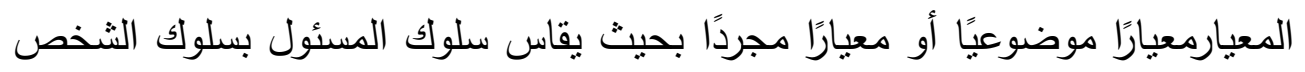

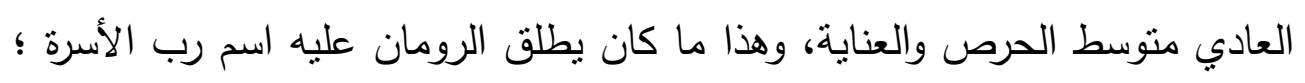


لأن قياس التعدي هنا بمعيار شخصي يؤدي لإفلات الثخص شديد الإهمال من المسئولية حتى عن خطئه العادي ومحاسبة الثخص شديد الحرص من خطأه التافه، ويقتضي الأخذ بالمعيار الموضوعي والاعتداد بالظروف الخارجية التي يكون فيها من

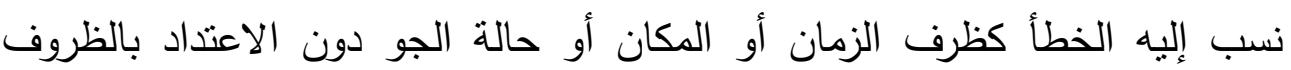
الشخصية للفاعل كضعف البصرأوحدة المزاج أو عمر الفاعل أو جنسه. وكما يكون الخطأ بفعل إيجابي فإنه يكون بفعل سلبي (الترك) ويتخذ الخطأ السلبي إحدى صورتين : الأولى هي صورة الامتتاع عن القيام بواجب يفرضه القانون وهوالامتتاع المضمون بنشاط من المسئول، والصورة الثانية الامتتاع المجرد بحيث يأخذ الثخص فيه موقفا سلبيا تجاه حالة يستطيع فيها دفع الضرر عن الغير دون أن يكون عليه الالتزام بذلك.

أما شراح الفقه الفرنسي،(9) فإنهم لا يقيمون المسئولية تماماً، غير أن معظم الفقهاء في فرنسا لا يتجهون لهذه التفرقة ويقيمون المسئولية على الممتع سواء كان امتتاعه مجرداً أو مصحوباً بنشاط سابق.

ويكون عبء إثبات التعدي يكون على المضرور الذي يطالب بالتعويض عن الضرر الذي لحقه جراء هذا التعدى، فعلى الدائن إثبات انحراف مدينه عن سلوك الرجل المعتاد مما رثب المسئولية في ذمته وله في سبيل ذلك الإثبات بكافة طرق الإثبات وذلك إعمالاً لقاعدة الوضع الثابت أصلا المستتد عليها فقهاً وقضاء حيث أن تطبيق هذة القاعدة يقتضي تكليف الثخص بماهو ثابت أصلا، وفي هذا المجال يفترض أن الثخص لم يتعدي علي أحد ومن يري غير ذلك يقع عليه عبء الإثبات. البند الثاني : المعيار شخصي وفي المعيار الثخصي ينظر إلى الفعل من خلال فاعل محدث الضرر الذي نتج عن خطأه هو شخص شديد الحرص أما متوسط الحرص أم شديد الإهمال 
فإن المقياس الثخصي يستلزم أن ننظر إلى الشخص المعتدي نفسه لا إلى التعدي في حد ذاته، أو ننظر إلى التعدي مـن خـلال شـخص المعتدي، فالمقياس الشخصي على هذا النحو لا شك فيه أنه غيرعادل إذ يأخذ كل شخص بصورة منفرده ويقيس مسئوليته بمعيار فطنته ويقظته وهو في ذلك الوقت يربط بين الخطأ القانوني والخطأ الأدبي.

إن في المقيـاس الثخصـي هذا عيب جـوهري لا يـصلح أن يكون مقياسـا منضبطا وافيا بـالغرض، فهو يقتضي أن ينسب الانحراف في السلوك إلى صساحبه فنظظر إلى الثخص ونكثف عما فيه من يقظة وما درج عليه من عادات، وهذا كله أمر خفي يستعصي على الباحث المدقق كشفه، ثم هو بعد ذلك يختلف من شخص

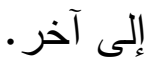
فالانحراف عن السلوك المـألوف، يراه الناس في العادة انحرافا محققا يكون تعديا بالنسبة إلى الشخص ذي فطنة أو شخص عادي، ولا يكون كذلك بالنسبة إلى شخص دون الاثنين في اليقظة.

وإن فشل هذا المقيـاس في تحديد الانحـراف الـذي يعد خطـأ رجـح الأخذـ بالمقياس الموضوعي دون المقياس الشخصي، فيقاس الانحراف بسلوك شخص نجرده من ظروفه الشخصية، هذا الشخص المجرد هو الشخص العادي الذي يمثل جمهور الناس، فلا هو خـارق الذكاء شديد اليقظة فيرفع إلى الذروة، ولا هو محدود اليقظة هونة

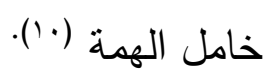
الغصن الثاني : الركن المعنوي ( الادراك ). وهو الادراك بالقيام بالفعل الضار ، وكذا إدرالك النتيجه التي تترتب على القيام بذلك الفعل الضار، هو أن يكون مرتكب الفعل الضار قد قصد الإضرار بالغير، فإذا توافر هذا القصد تحقق العنصر النفسي للخطأ ( الركن المعنوي ). 
إذ لا يكفي توافر الركن الموضوعي ليقوم الخطأكبل يجب لتحققه أن يكون من

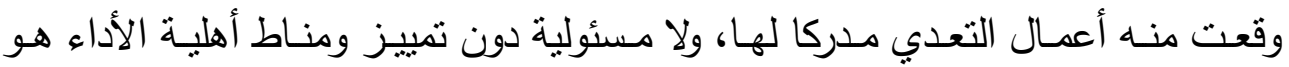
التمييز وأهليـة الأداء هي " صـلاحية الشخص لإعمال إدراكه إعمالا من شـأنه ترتيب

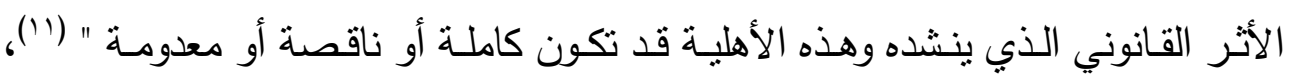

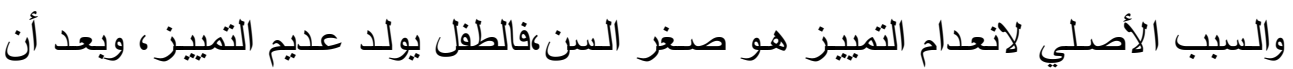
يصبح مميزا قد ينعدم التمييز لديه بعد ذلك لأسباب عارضة طويلة الأمد أو قصيرة الأمد. ونـادي أصـحاب النظربـة الماديـة فـي المسئولية التقــيرية، والتـي تنبـي المسئولية على أساس تحمل التبعة لا على الخطأ (r')، إذ يقررون المسئولية حتى إذا انعدم التمييز، فغير المميز إذا لـم يكن قـادرًا على ارتكاب الخطـأ يستطيع إحداث

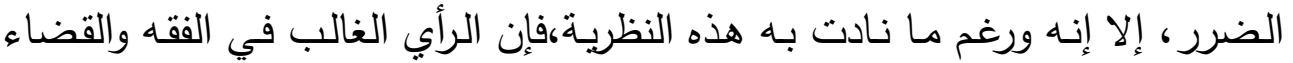
يتطلب لقيام المسئولية التقصيرية توافر التمبيز في مرتكب الخطأ، إلا إنه يسعى في نفس الوقت إلى التضبيق من نطاق هذا المبدأ بوسائل شتى نزولا منه على اعتبارات العدالة، ومن ذللك أقروا إمكانية الرجوع على المكلف بالرقابة بالتعويض إذا كان لعديم

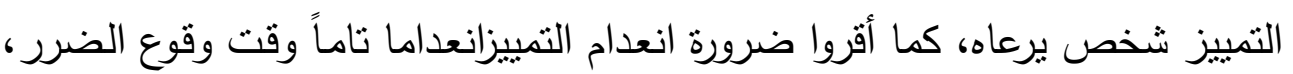

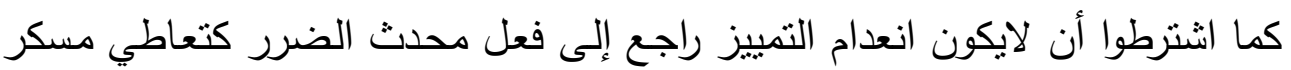
أو مخدر لتوجيه غير المتميز إلى ارتكاب الخطأ وإحداث الضرر.

\section{البند الأول : موقف المشرع المصري}

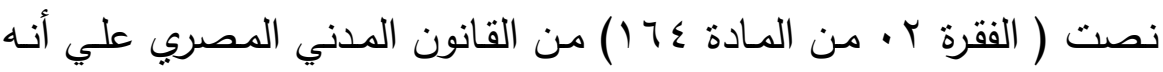
"r- ومع ذللك إذا وقع الضرر من شخص غيرمميز ولم يكن هناك من هو مسئول عنه أو تعذر الحصول علي تعويض من المسئول جاز للقاضي ان يلزم من وقع منه الضرر بتعويض عادل مراعيا في ذلك مركز الخصوم ".

وتبين هذه المـادة أن مسئولية عديم التمييز تتميز بـأمرين : الأول أنها مسئولية مشروطة، وشرطها أن المضرور لا يستطيع الحصول على تعويض من شخص آخر غير 
عديم التمييز شريطة ألا يكون لهذا الأخير شخص آخر يكفله كوالدهأو أمه أو عمه، أو أن

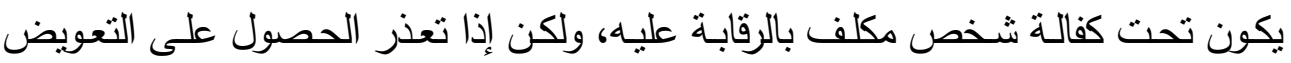
لانتفاء قربنة الخطأ من جانب المذكورين ؛لأنه قابل لإثبات العكس، أوأنهم لم يستطيعوا نفي الخطأ من جانبهم ولكنهم كانوا معسرين فعندئذ يرجع على عديم التمبيز بالتعويض. أمـا الأمر الثاني،فهي مسئولية مخففة و جوازيـة للقاضـي فيما يتعلق بالحكم

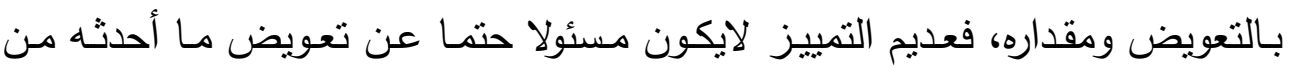
ضرر تعويضا كاملا وعلة ذلك أن هذه المسئولية لا تبنى على الخطأ بل على تحمل لإنل

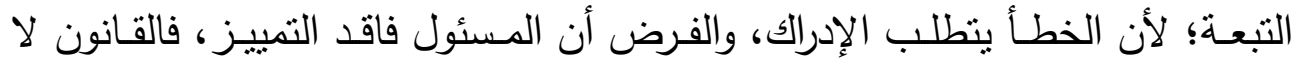
يحملـه التبعـة عـن الأضـرار؛ لأن حكم التعـويض تبعـا لتقدير القاضـي وذلـك لان مسئولية عديم التميز تقوم على أساس العدالة لا على أساس القانون. الفرع الرابع : إثبات الخطأ. إن المسئولية عن الأعمـال الشخصية أي عن عمـل شخصي يصدر مـن

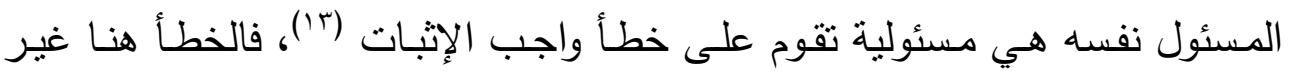
مفترض، بـل يكلف الدائن إثباتهه في جانب المدين، وهذه هي القاعدة العامـة في المسئولية التقصيرية الذي لـم ينحرف القانون عنها إلى مسئولية تقوم على خطأ مفترض، إلا في حالات معينة حصرتها النصوص القانونيـة، فعلى الدائن في هذه الحالة أن يثبت أن المدين قد انحرف عن السلوك المـألوف للرجل العادي فترتبت، المسئولية في ذمته أي أن على الدائن أن يثبت أن المدين قد أخل بالتزامه القانوني،

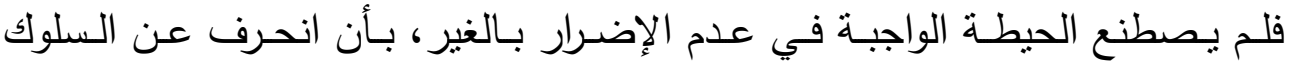
المألوف للرجل العادي فألحق الضرر به. الغصن الأول : إثبات الخطأ عند المشرع المصري. إن المشرع المصري وفي التقنين المدني المصري قد أقر بأن الأصـل في

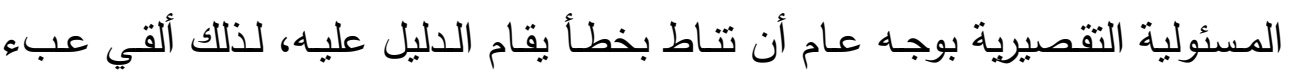


الإثبات فيها على المضرور وهو الدائن (؛')، كما إن الخطأ واقعة مادية،فإن إثباته يكون بكافة طرق الإثبات، وكذللك أنه لا يكفي لقيام المسئولية التقصيرية عن العمل

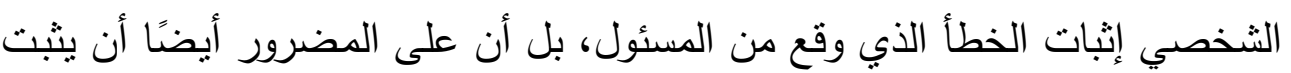
علاقة السبيية بين الخطأ والضرر اللاحق به. الغصن الثاني : إثبات الخطأ عند المشرع الفرنسي. فقد نص المشرع الفرنسي في المادة ( r r I ) من القانون المدني الفرنسي على أن المسئولية المبنية على هذه المادة يقع عبء إثبات الخطأ الناتج عنه الضرر على عـاتق المضرور ، وهـذا تطبيقـا للمبـدأ العـام في مجـال الإثبـات والـذي يلـزم المضرور بتقديم الدليل على أن الضرر الذي أصابه كان نتيجة للخطأ الذي أقترفهـ المسئول وهذا يجب الإشارة إلى أن إثبات الخطأ قد لا يصل إلى مرحلة اليقين؛ وذلك بسبب عدم إمكانية تحديد السبب الحقيقي للضرر ، كأن يكون مثنا السبب مجهول فإن المضرور الذي يعتمد على خطأ خصمه ترفض دعواه ؛لأنه في المسئولية المستمدة

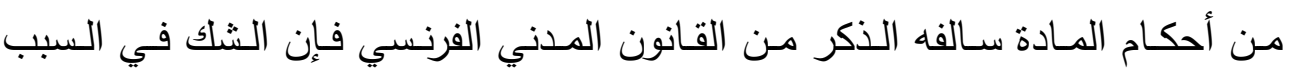
الحقيقي لوقوع الضرر يستفيد منـه المـدعى عليهه،وبالتالي فـإن الضحية لا يمكنها الحصول على تعويض، وهذا بعكس المسئولية عن فعل الأثياء،فإن الثك يفسر لصالح المضرور " المدعي " في دعوى التعويض، فإن هذه الأسباب وغيرها أدت إلى لى تضخم عدد قضايا المسئولية المدنية بما لم يخطر ببال المشرع عند وضعه لقانون

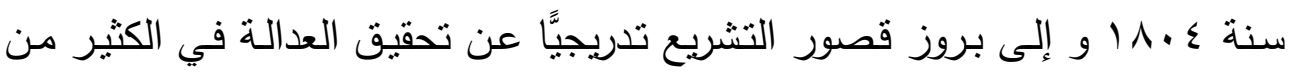
هذه القضايا،بسبب عجز المضرورين إثبات خطأ من تسببوا في الضرر لهم، فدفع ذللك الفقه أولا ثم المحاكم إلى العمل على استتباط نظريات جديدة وإيجاد حلول مختلفة بالتوسع في تفسير النصوص توسعًا خرج بها أحيانا عن قصد المشرع وقد بلغ الثعور بهذا النقص إلى التقنين الفرنسي؛ إذ بدأت صعوبة الإثبات بنوع خاص في المسائل المذكورة منل حوادث العمل، وحوادث النقل والحوادث الناشئة عن الآلات(10). 


\section{المبحث الثاني \\ تقدير التعويض}

ويعد التقديرالقضائي للتعويض متى لم يحدد القانون أحكاما لحساب التعويض

أولـم تـذهب إرادة المتعاقدين إلى تقديره، كـان المجـال مفتوحـا أمسام القاضـي ليقدره

وينصب تقديرالتعويض على الضرر اللاحق بالمتضرر ، لذا يتعين علي القاضـي لتقدير التعويض توافر عدة عناصر أساسية وهي مراعاة الظروف الملابسة للضر نفسه من حيث الزمان والمكان ملاحظاً فيها حالة المضرور والمسئول، وكذلك النظر وهرئر فراهر إلى جسامة الضرر الذي أصساب المضرور و مراعاة حسن النيـة، أو سوئها وانتفاء الغـش، وهـذا العنصر خـاص بالمسئولية العقديـة ؛وذلك لأن العبـرة في المسئولية التقصيرية بتوافر أركانها الثلاتة من خطأ وضـرر وعلاقة سببية وإلا اعتبر حكماً مخالفاً للعدالة.

فسلطة القاضي في تقدير حق المضرور تقديريه في التعويض بالإضافة إلى تحديد طريقة التعويض التي يراها لازمة لجبر الضرر ماديًّا كان أو معنويَّا، ولكن هذا لا يعني أن محكمـة الموضـوع لا تخضع لرقابـة محكمـة النقض حيث قضت محكمـة

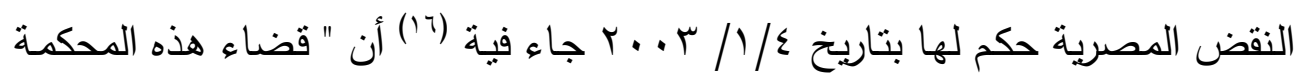
قد استقر على أن لمحكمة الموضوع وهي تقدر قيمة التعويض أن تزن بميزان القانون ما يقدم لها من أدلة وبيانات على قيام الضرر وتحدد عناصره، فإذا ما صدر حكمها محيطاً بكافة عناصر الضرر الناتج عن خطأ المدعى عليه شاملاً ما لحق المضرور من خسارة وما فاته من كسب،ققد أصابت صحيح حكم القانون في ما انتهت إليه من تقدير لقيمة التعويض، بغير معقب عليها فيما هو متروك لتقديرها ووزنها لمدى الضرر وقيمة التعويض الجابر له طالما كان تقديرها سائغاً و مستمداً من أصول ماديـة تتتجه هئه

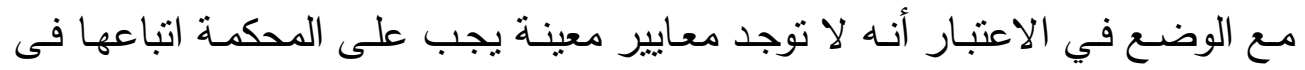


خصوص تقدير مبلغ التعويض منى بينت عناصر الضرر المستوجب للتعويض، ومن ثم فإنه لا تثريب عليها إن هي قضت بتعويض إجمالى عن أضرار متعددة ما دامت قد ناقتت كل عنصر على حدة وبينت وجه أحقية طلب التعويض فيه أو عدم أحقيته "

\section{المطلب الأول}

\section{سلطة قاضي الموضوع في تقدير التعويض}

متى تبين لقاضي الموضوع قيام شروط المسئولية المدنية، حكم بالتعوبض،

فعندما ترفع أمام القاضي دعوى للمطالبة بالتعويض، وجب عليه في مرحلة أولى أن يفهم الوقائع المطروحة أمامه، وفي مرحلة ثانية تكييفها بتطبيق النص القانوني الملائم عليها من خلا التأكد بأنها كافية لتنكل أركان المسئولية المدنية ليتأنى له في مرحلة

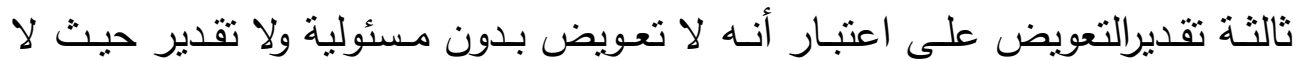
تعويض، على أن يحدد بطريقة موازيـة الطريقة التي يتم بها هذا التعويض، ويختار القاضي طريقة التعويض من خلال تحديد ما هو الأنسب لإصلاح الضرر معتمدا في ذلك على نص المادة (ب7 ( ) من القانون المدني المصري : " كل خطأ سبب ضرراً للغير يلزم من ارتكبه بالتعويض "

وتبعا لما ورد في نص المادة VI من القانون المدني المصري :" r- ويقدر

التعويض بالنقد على انه يجوز للقاضى، تبعا للظروف وبناء على طلب المضرور،

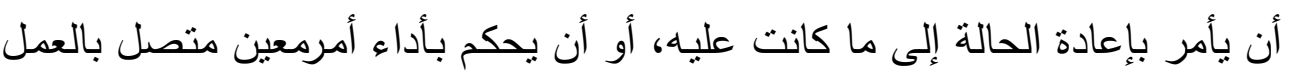
غير المشروع، وذللك على سبيل التعويض "

وبناء علي ماتقدم يحدد قاضي الموضوع طريقة التعويض نبعا للظروف، فيجوز أن يكون التعويض مايَّا، أو أن يأمر بإعادة الحالة إلى ما كان عليها إذا كان ذلك ممكناً، وعليه فيان طريقة إصـلاح الضرر تختلف حسبما تكون الظروف الملابسة لحالة النزاع المطروح، وبمـا يبدي المضرور في طلباته عنها كمـا أنها تختلف في نطاق المسئولية 
العقديـة عنهـا في نطـاق المسئولية التقصيرية، فـإذا كان التنفيذ العينـي هو الأصـل في المسئولية التعاقدية، فعلى النقيض من ذلك في نطاق المسئولية التقصيرية.

ويذهب بعض الفقهاء (V) إلى أن التتفيذ العينـي يختلف عـن التعـوبض العيني، فالأول محله المسئولية العقدية دون المسئولية التقصيرية، وبالرجوع إلى المواد التي خصصها المشرع المدني للتنفيذ العيني، نجدها تبحث عن كيفية تتفيذ الالتزامات العقديـة فقط دون إثـارة للمسئولية التقصيرية، إضـافة إلى أن الدائن في المسئولية العقديـة عندما يلجأ إلى القضاء ملتمسا الحكم لـه بالتتفيذ العيني، فهو يلتمس إلزام

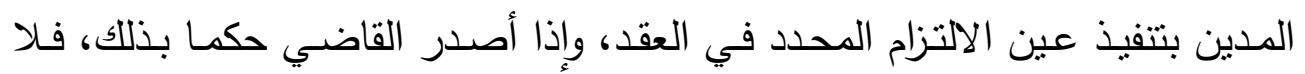
يكون قد أصدر حكما بالتعويض للمضرور ، وحتى إذا ما رتب له تعويضا عن التأخر في الوفاء بالالتزام الأصلي إلى جانب التنفيذ العيني، فهذا التعويض لا يغيرمن حقيقة

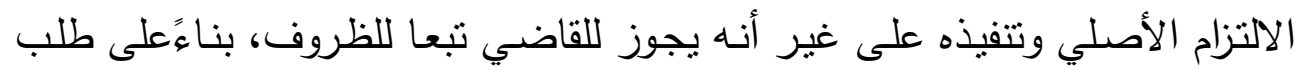
المضرور أن يأمر بإعادة الحالة إلى ما كانت عليه قبل التهاه التعاقد.

أمـا التعويض العينـي فمجاله المسئولية التقصيرية،ويحمل في طياته معنى التعويض ؛لأن الحكم الصادر به لا يقصد تتبيه المدين إلى تقاعسه وحثه على تتفيذ التزامه السابق عينا، وإنما الحكم الصادر هنا يتضمن أن المدين قد أخل بواجب عدم إلى لهاب الإضرار بالغير، فيتعين إصلاح هذا الضرر بتوقيف هذا الإخلا، وهذا هو التعويض العيني وهو ما قصده المشرع، أمسا التعويض بمقابل فهو الذي يصلح في في المسئولية العقدية متى استحال تتفيذ الالتزام عينا وهو القاعدة العامـة في المسئولية التقصيرية لاستحالة التعوبض العيني في أغلب الأحيان. وفي سبيل تحقيق ذلك مكن المشرع القاضي بموجب القانون من اللجوء إلى ذوي الخبرة والاختصاص وللقاضـي اعتمـاد مـا وصـل إلبـه الخبيـر في حكمـه ولـه رفضها، كما بإمكانه الأمر بخبرة مضادة للوقوف على الضرر الفعلي فتقدير أعمال الخبير أمر تنتقل به محكمة الموضوع ولا رقيب عليها فيها من محكمة النقض. بإنها. 
وفي ذلك ذهبت محكمه النقض المصرية في حكم لها بتاريخ V/T/T9/ •

ورد فيـه (1) أن " تقدير التعـويض مـن إطلاقـات محكمـة الموضـوع بحسب مـا تـراه مناسباً مستهدية في ذلك بكافة الظروف والملابسات في الدعوى، وأن تعديل محكمة الاستئناف مبلغ التعويض فقط يوجب عليها ذكر الأسباب التي اقتضت هذا التعديل ". أما إذا تعدد المسئولون عن عمل ضـار كانوا جميعا متضامنين في التزامهم بتعويض الضرر، وتكون المسئولية فيما بينهم بالتساوي إلا إذا عين القاضي نصيب كل منهم في الالتزام بالتعويض، فقد يتعدد المسئولون عن العمل غير المشروع، بأن ينسب إلى كل منهم خطأ يساهم في إحداث ذات الضرر، فيمكن للقاضسي أن يوزع المسئولية بالتساوي، ولكن إذا استطاع القاضي أن يحدد مدى جسامة الخطأ لكل من

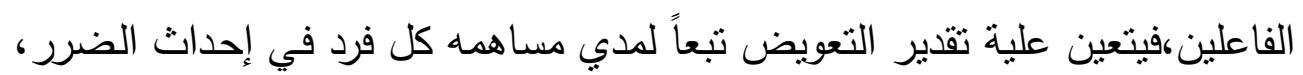
وأن أساس التقسيم في هذه الحالة هو مدى جسامة الخطأ. وكذلك إذا سـاهم المـرور بخطئه في إحداث الضرر، فـإن ذلك يوجب تخفيف المسئولية برفع جزء من التعويض عن كاهل المسئول، وقد يعفى تماما من التعويض، وذلك حسب مدى جسامة الخطأ المنسوب للمضرور، فيجوز للقاضي أن ينقص مقدار التعويض إذا كان المضرور بخطئه قد اشترك في إحداث الضرر أو زاد فيه، فتكون جسامة الخطأ الصادر من المسئول محل اعتبار في تحديد نصيبه في إني التعويض، وتوزيع المسئولية بينه وبين المضرور ، فمتى تحققت المسئولية قدرالتعويض بقرر جسامة الضررلاجسامة الخطأ.

\section{المطلب الثاني}

\section{التقدير الملزم للقاضي}

الالتزام بالتعويض التزام جزائي يفرضه القانون على كل من تسبب بخطئه في

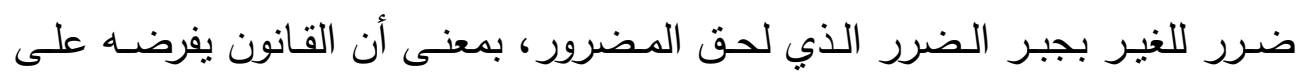


المسئول عنه جزاء إخلاله بواجب معين وتقدير هذا التعويض يتولاه القاضي، وهو الأصل ويحدده وفقا لسلطته التقديرية ومع ذلك وفي أحوال معينة وضع المشروع قيودا على هذه السلطة التقديرية الواسعة والممنوحة للقاضي فقد يقوم القانون بوضـع قواعد يتم من خلالها تحديد التعويض بمبلغ جزافي وقد يترك الأمر لحرية الأفراد يحددونه وفقا لما يبدو لهم من ظروف التعاملات وملابساتها وفي كلتا الحالتين ألزم المشرع

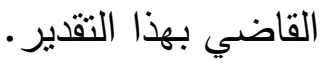

الفرع الأول : التقدير القانوني للتعويض.

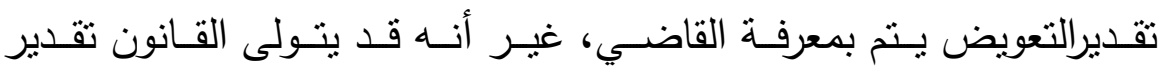
التعويض، وذللك بوضع أحكام وقواعد يسمح تطبيقها بالوصول إلى مبلغ جزافي يكون هو التعويض، كما فعل بالنسبة لبعض القوانين الخاصة كقانون التعويض عن حوادث السيارات، وقانون حوادث العمل، وكذلك الأحكام التي تتظم الفوائد القانونيه. وفي ذلك ذهبت محكمه النقض المصرية في حكم لها بتاريخ ر م/ • / / 1970

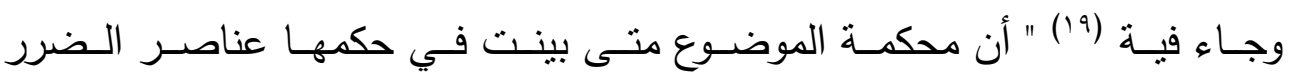
المستوجب للتعويض، فإن تقدير مبلغ التعويض الجابر لهذا الضرر هو مما تستقل به مـا دام لا يوجد في القانون نص يلزم بإتبـاع معاييرمعينـة في خصوصه ولا تثريب

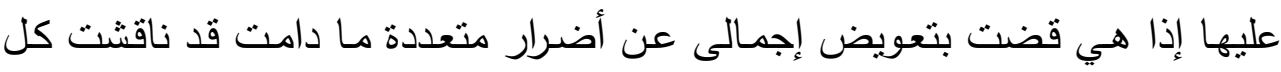
عنصر منها على حده وبينت وجه أحقيه طالب التعويض فيه أو عدم أحقيته، فإذا كان الحكم الابتدائي قد أوضح في أسبابه - التى أقرها الحكم المطعون فيه وأحذ بها - عناصـر الضرر الذي لحق المطعون ضـدهم بسبب خطـأ الطاعنـة وبين وجـه أحقيتهم في التعويض عن كل عنصر ، فإن محكمة الإستئناف وقد رأت أن مبلغ بـن التعويض المحكوم به لا يكفى في نظرها لجبر هذه الأضرار فرفعته إلى مبلغ أكبر لما

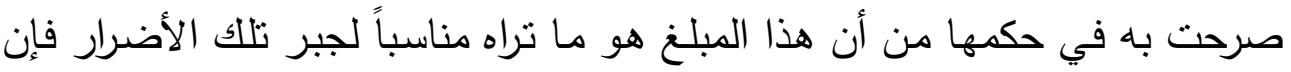
في هذا الذي ذكرته ما يكفى لتعليل مخالفتها لمحكمة أول درجة في تقدير التعويض" 
فيعمد المشرع في بعض الأحيان إلى تحديد المسئولية، فيقوم بوضـع أسس لتقدير التعويض ولو بصفة غير مباشرة، من خلال تحديد سقف لا يمكن أن يتجاوزه التعويض، ولو كان الضرر الواقعي يجاوز هذا القدر فمتى وصل الضرر حداً من الجسامة يناسب الحد الأقصى الذي حدده المشرع للتعوبض أو فاقه كنا أمام تقدير قانوني للتعويض، أمـا قبـل ذلك الحـد فالتقدير متروك للقاضـي يقدره بمـا يتتاسـب والضرر ويمارسه وفقا للقواعد العامة.

وبذللك تقدرالمحكمـه عناصر الضرر التى تدخل فى حساب التعويض وتخضع محكمة الموضوعفيها لمحكمة النقض في تقدير التعويض هو بقيمة الضرر وقت الحكم لا وقت وقوع الضرر وعلة ذلك أن القانون لا يمنع التعويض عن الكسب الغائب. الفرع الثاني : التقدير الاتفاقي للتعويض

أجازالقانون للمتعاقدين اللجوء إلى تقدير مسبق للتعويض في العقد الذي يرتب التزاماتهما المتبادلة في حالة استحالة تتفيذ المدين لإحدى هذه الالتزامات المترتبة في ذمته عينا أوالتأخر في تتفيذها، ويستحق هذا التعويض المسبق للدائن متى ثبت أن لن الن إخلال المدين قد ألحق بـه ضررا يدرجه المتعاقدان في العقد كبند فيه أو في الاتفاق هين فئن التعاقدي المبرم بينهم وقد وضـع المشرع أحكام خاصـة بالشرط الجزائي، تختلف عن لن تللك التي يخضع لها عقد الصلح.

وهناك طريقة أخرى قد يلجأ إليها الأطراف يكون من شأنها تحديد مسئولية المسئول (·r) ويترتب عليها تعديل في أحكام التعويض والغالب في الاتفاق على تحديد المسئولية المدنية أن يكون اتفاقا على الإعفاء منها برفعها كلية عن مرتكب الفعل الضارأو المخل بالتزامه ومنع مطالبته بالتعويض الذي تقضي بـه القواعد العامـة، وقد يقتصر التعديل محل هذا الاتفاق على تخفيف المسئولية برفع جزء منها من على عاتق المسئول وحصرمسألته على الجزء الباقي، كما يجوز بالعكس من ذلك أن يقصد بالتعديل زيادة مسئولية مرتكب الفعل الضارعما تقضي به القواعد العامة 


\section{الخاتمة:}

إن وظيفة التعويض واحدة هي جبر الضرر جبراً كاملاً، ولا عبرة بجسامة

الخطأ في تقدير التعويض؛ لأن هذا ما بتتافي مع تلك الوظيفة، والمسئول هو وحده هي هـره الملتزم بـالتعويض تجـاه المضرور ؛ لأن هذا جزاء خطئه الملوم الذي لا يتحمل بـه

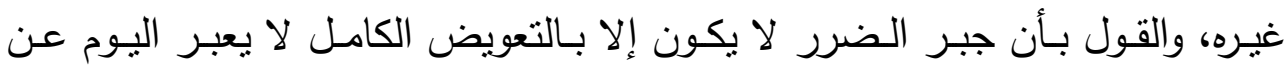
الواقع،بسبب تدخل الاتجاه نحو عدالة التعويض كضريبة للتوسع في المسئولية من ناحية، وبسبب تدخل النظرة الاجتماعية في معنى جبر الضرر من ناحية أخرى، وقد تحقق ذلك بـالطرق القانونية، كتحديد المسئولية، أو التعويضات الجزافية، وبـالطريق القضائي باتبـاع معـايير العدالـة أو معسيير التخفيف، وبـذلك اكتسبت وظيفـة جبر

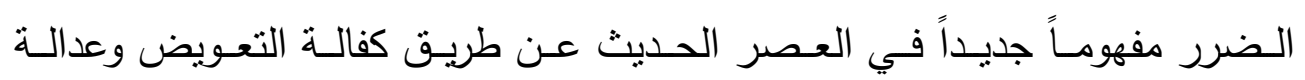
التعـويض، هـو المفهوم الاجتمـاعي، سـواء في قيـاس الفعـل الـذي يوجـب الالتـزام بالتعويض أو في الوفاء بالتعويض للمضرور الهور

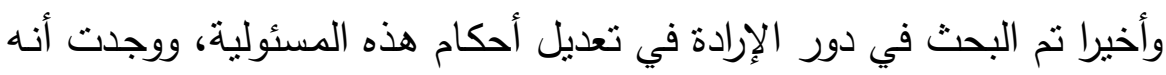

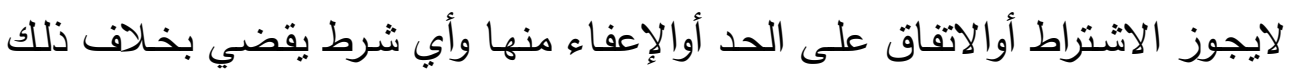
يعد باطلا قانونًا 


\section{قائمه المراجع والمصادر}

ا. جميل الثرقاوي: النظرية العامة للالنزام مصادر الالتزام. القاهرة : دار النهضة العربية.

r. منذر الفضل : النظرية العامة للالتزامات: مكتبة دار النقافة للنشر والنوزيع. 1997

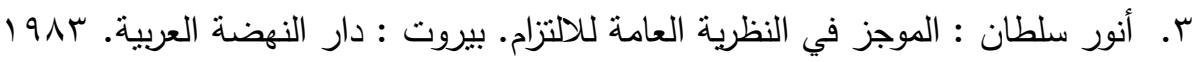

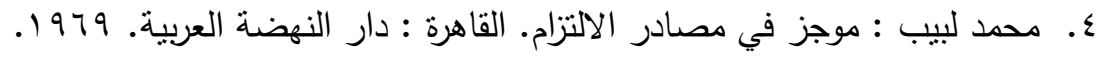

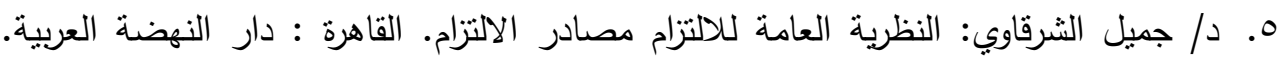

T. I دVV د. محمد لبيب شنب، دروس فى نظرية الالتزام، دار النهضة العربية،

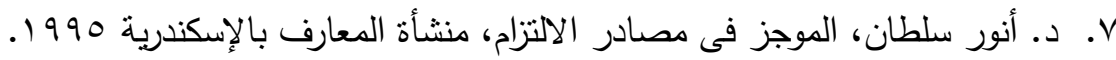

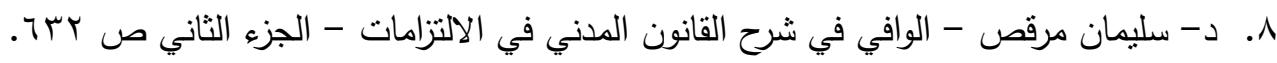

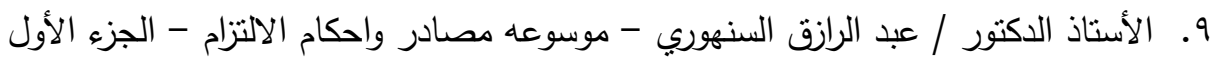

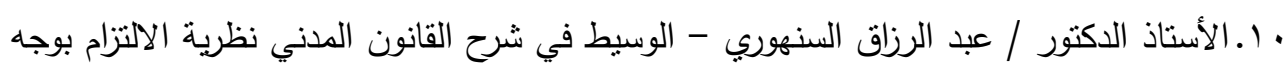

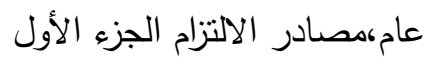
11.د/ جميل الثرقاوي : النظرية العامة للالتزام مصادر الالتزام - القاهرة، دار النهضة العربية. 1911

rا. أ. د/ جميل الثرقاوي : النظرية العامة للالتزام مصادر الالتزام - القاهرة، دار النهضة

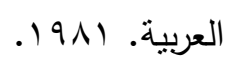

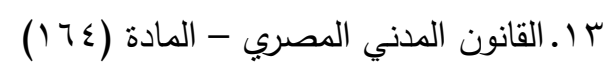

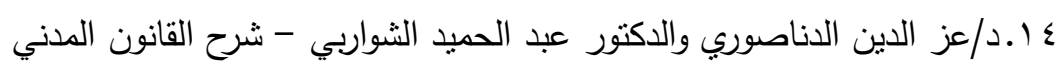
1 الأستاذ الدكتور / عبد الرزاق السنهوري - الوسيط Y 17

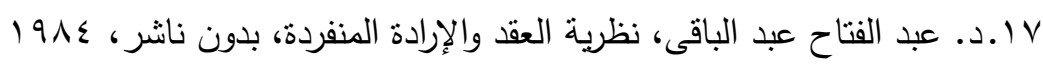

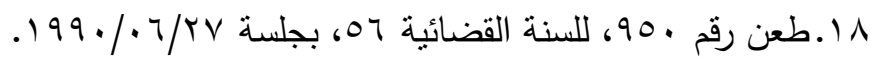

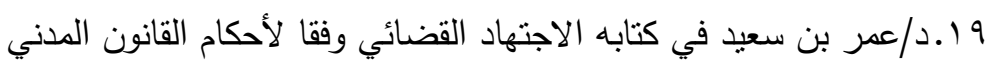

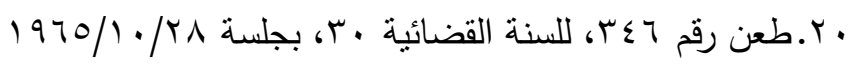

